\title{
STRATEGI PENINGKATAN RETRIBUSI PASAR YOUTEFA, SEBAGAI SALAH SATU SUMBER PENDAPATAN ASLI DAERAH
}

( Studi Kasus Pengelolaan Retribusi Pasar Youtefa Pada Dinas Pendapatan Daerah Kota Jayapura)

\author{
Penulis: \\ Yuli Antikasari ${ }^{1}$ \\ Yuli.antsar69@gmail.com \\ Westim Ratang ${ }^{2}$ \\ westim_ratang@yahoo.co.id \\ Agustina Sanggrangbano ${ }^{3}$ \\ Ina_djarum@yahoo.com
}

\begin{abstract}
This paper reveals the study of organisational environment change and local market levies. The study uses a model of interaction analysis and SWOT analysis. The main problems faced by the market management are the low ability and skills of employees, weak supervision and law enforcement, low levels of merchant awareness of the rules, and the targeting error. This study formulates strategic policies to overcome the problems faced in collecting local market levies.
\end{abstract}

Keywords: organisational change, local market levies, SWOT Analysis

\section{PENDAHULUAN}

Menghadapi fenomena rendahnya kemampuan keuangan daerah yang ditandai antara lain masih rendahnya pajak dan retribusi daerah, selanjutnya pemerintah pusat menjawab permasalahan tersebut dengan dikeluarkannya UU/34/2000 berikut peraturan pemerintah nomor 65 dan nomor 66 tentang pajak dan retribusi yang merupakan penyempurnaan atas UU/18/1997.

Esensi dari reformasi kebijakan tersebut adalah memberikan ruang gerak yang lebih luas kepada daerah baik propinsi, kabupaten dan kota, untuk menggali segenap potensi pajak dan retribusi daerah di wilayahnya. Akhirnya diharapkan akan dapat meningkatkan kapasitas keuangan daerah sejalan dengan nafas kebijakan otonomi daerah.

Kebijakan tersebut tentunya untuk mengurangi ketergantungan daerah atas subsidi pusat dan di sisi lain daerah dituntut untuk mampu secara cermat menjawab permasalahan yang mendasar, mengidentifikasi sumber daya pembangunan, menggali dan memanfaatkan potensi wilayah dalam rangka penyelenggaraan pemerintahan, pembangunan dan pelayanan kepada masyarakat.

Dalam UU/22/1999 tentang Pemerintahan Daerah yang lebih dikenal dengan sebutan

\footnotetext{
${ }^{1}$ Alumni Mahasiswa Magister Keuangan Daerah Universitas Cenderawasih

2 Staf Dosen Jurusan Manajemen Fakultas Ekonomi \& Bisnis Universitas Cenderawasih

${ }^{3}$ Staf Dosen Jurusan Ekonomi Fakultas Ekonomi \& Bisnis Universitas Cenderawasih
} 
otonomi daerah, dan UU/25/1999 tentang Perimbangan Keuangan Antara Pemerintah Pusat dan Daerah dalam hal ini daerah dituntut untuk lebih dapat mandiri dalam mengelola sumber daya secara optimal.

Keuangan daerah merupakan salah satu faktor penting dalam mengukur secara nyata kemampuan daerah dalam melaksanakan otonomi. Menurut Kaho (2013) salah satu kriteria penting untuk mengetahui secara nyata kemampuan daerah dalam mengatur dan mengurus rumah tangganya adalah kemampuan "Self Supporting" dalam bidang keuangan. Dengan perkataan lain, faktor keuangan daerah merupakan faktor esensial dalam mengukur tingkat kemampuan daerah dalam melaksanakan otonominya.

Pendapatan Asli Daerah merupakan salah satu komponen sumber penerimaan keuangan daerah, di samping penerimaan lainnya. Meskipun demikian, proporsi Pendapatan Asli Daerah terhadap total penerimaan tetap merupakan indikasi "Derajat Kemandirian Keuangan Suatu Daerah" (Santoso, 1995).

Dalam rangka mewujudkan otonomi daerah maka salah satu upaya yang harus dilakukan adalah meningkatkan derajat kemandirian keuangan daerah, dalam hal ini adalah meningkatkan dan mengoptimalkan pendapatan asli daerah (PAD), yang terdiri dari hasil pajak daerah, perusahaan daerah dan penerimaan lain-lain usaha daerah yang sah. Untuk lebih jelasnya dapat dilihat pada Tabel 1 berikut:

Tabel 1

Data Pertumbuhan Target dan Realisasi Pendapatan Asli Daerah (PAD) Kota Jayapura Periode Tahun 2009-2013

\begin{tabular}{|c|c|c|c|c|}
\hline No. & Tahun & Target & Realisasi & $\%$ \\
\hline 1. & 2009 & 35.345 .500 .000 & 42.991 .003 .113 & 121,63 \\
\hline 2. & 2010 & 50.500 .000 .000 & 50.576 .675 .159 & 100,15 \\
\hline 3. & 2011 & 59.240 .000 .000 & 61.584 .199 .232 & 103,96 \\
\hline 4. & 2012 & 66.627 .000 .000 & 76.580 .358 .430 & 114,94 \\
\hline 5. & 2013 & 90.000 .000 .000 & 100.225 .833 .150 & 111,36 \\
\hline \multicolumn{2}{|c|}{ Rata-rata } & $66.391 .613 .816,80$ & 110,41 \\
\hline
\end{tabular}

\section{Sumber : Dinas Pendapatan Daerah Kota Jayapura}

Tabel 1 di atas memperlihatkan bahwa realisasi penerimaan asli daerah dalam kurun waktu tahun 2009 sampai dengan tahun 2013 selalu melebihi target yang ditetapkan. Capaian tertinggi terjadi pada tahun 2009 dimana realisasi penerimaan PAD sebesar 121,63 persen dari target di awal tahun sebesar Rp35.345.500.000. Rata-rata realisasi pada kurun waktu tersebut adalah sebesar 110,41 persen dengan nilai rata-rata PAD sebesar Rp66.391.613.816,80. Ini dapat menjadi bukti bahwa kota Jayapura dalam pengelolaan PAD dari tahun ke tahun selalu serius menghimpun pendapatan yang berasal dari dalam perekonomian sendiri dalam rangka mewujudkan kemandirian fiskal.

Secara empirik pungutan retribusi di Kota Jayapura menunjukkan kontribusi yang cukup besar terhadap PAD dikarenakan didukung oleh lima sektor retribusi unggulan yaitu (1) Retribusi pelayanan kesehatan (2) Retribusi pasar (3) Retribusi kekayaan daerah (4) 
Retribusi ijin mendirikan bangunan(5) Retribusi pengujian kendaraan bermotor, maka perlu kiranya dipertimbangkan pengelolaan retribusi dengan tepat dan benar, baik yang berhubungan dengan penentuan tarif, penentuan obyek, cara penetapan pungutan, administrasi pemungutan, tenaga dan fasilitas-fasilitas yang timbul diakibatkan oleh pungutan retribusi.

Salah satu sektor retribusi daerah yang potensial di Kota Jayapura adalah retribusi pasar. Pendekatan yang dilakukan dalam upaya meningkatkan retribusi daerah khususnya retribusi pasar selain melalui ekstensifikasi juga dengan pendekatan intensifikasi yang intinya adalah bagaimana pemerintah kebupatan khususnya Dinas Pendapatan Daerah dapat memperbaiki manajemen pengelolaan retribusi daerah khususnya retribusi pasar serta mampu menemukan strategi baru untuk meningkatkan penerimaan retribusi pasar secara proporsional.

Secara umum pengelolaan retribusi pasar di Kota Jayapura membutuhkan penanganan yang serius dan hati-hati karena dari segi pendapatan pasar dituntut untuk selalu meningkatkan pendapatannya yang secara otomatis harus di imbangi dengan peningkatan kualitas pelayanan terhadap masyarakat dan pedagang.

Keunggulan utama retribusi daerah adalah karena pemungutan retribusi berdasarkan pada kontra prestasi yang disediakan oleh pemerintah daerah, sehingga memberikan kemungkinan dan keleluasaan kepada pemerintah daerah untuk terus mengupayakan pengembangan potensi dan mengelola retribusi guna meningkatkan pendapatan asli daerah Retribusi pasar menyumbangkan kontribusi terhadap retribusi daerah nomor dua terbesar setelah penerimaan pelayanan kesehatan.

Berdasarkan sumber dari Dispenda Kota Jayapura tahun 2013 bahwa lima komponen terbesar dari sektor retribusi daerah adalah (1) retribusi pelayanan kesehatan Rp. 10.502.648.000; (2) Retribusi pasar Rp. 1.630.487.000; (3) retribusi kekayaan daerah Rp, 682.829.000; (4) retribusi ijin mendirikan bangunan Rp. 604.700.900; (5) retribusi pengujian kendaraan bermotor Rp. 516.808.000. Untuk lebih jelasnya dapat dilihat realisasi penerimaan retribusi pasar yang ada di Kota Jayapura dapat dilihat pada Tabel 2 berikut :

\section{Tabel 2}

Penerimaan Retribusi Pasar Yang Ada di Kota Jayapura tahun 2009- 2013 (Rp000)

\begin{tabular}{|c|l|c|c|c|c|c|c|c|c|c|c|}
\hline No. & Nama Pasar & $\mathbf{2 0 0 9}$ & $\mathbf{\%}$ & $\mathbf{2 0 1 0}$ & $\mathbf{\%}$ & $\mathbf{2 0 1 1}$ & $\mathbf{\%}$ & $\mathbf{2 0 1 2}$ & $\mathbf{\%}$ & $\mathbf{2 0 1 3}$ & \% \\
\hline 1 & Youtefa & 122.716 .000 & 33,45 & 148.300 .000 & 36.96 & 82.136 .640 & 32.89 & 290.510 .000 & 56.90 & 301.576 .750 & 38.23 \\
\hline 2 & Hamadi & 95.910 .700 & 26.14 & 96.400 .600 & 24.03 & 72.726 .665 & 29.12 & 99.301 .000 & 19.45 & 199.610 .600 & 25.30 \\
\hline 3 & Entrop & 79.681 .000 & 21.72 & 88.000 .050 & 21.94 & 62.696 .595 & 25.11 & 70.504 .000 & 13.81 & 187.795 .850 & 23.80 \\
\hline 4 & Tanjung ria & 68.560 .000 & 18.69 & 68.508 .000 & 17.07 & 32.186 .600 & 12.88 & 50.200 .100 & 9.84 & 99.944 .300 & 12.67 \\
\hline \multicolumn{2}{|l|}{ Retribusi Pasar } & $\mathbf{3 6 6 . 8 6 7 . 7 0 0}$ & & $\mathbf{4 0 1 . 2 0 8 . 6 5 0}$ & & $\mathbf{2 4 9 . 7 4 6 . 5 0}$ & & $\mathbf{5 1 0 . 5 1 5 . 1 0}$ & & $\mathbf{7 8 8 . 9 2 7 . 5 0}$ & \\
\hline
\end{tabular}

Sumber: Dispenda Kota Jayapura

Tabel 2 di atas menunjukkan bahwa penerimaan retribusi Pasar Youtefa dari tahun anggaran (2009 s/d 2013) merupakan penyumbang retribusi terbesar dibandingkan dengan 
pasar-pasar lain yang ada di kota Jayapura. Namun demikian, dilihat dari persentase penerimaan retribusi pasar Youtefa dari tahun anggaran (2009 s/d 2013) mengalami peningkatan dan penurunan yaitu pada tahun 2009 persentase penerimaan retribusi pasar Youtefa sebesar 33,45 persen, pada tahun 2010 mengalami peningkatan dimana persentase penerimaan retribusi pasar Youtefa sebesar 36,96 persen, pada tahun 2011 persentase penerimaan retribusi pasar Youtefa menurun menjadi 32,89 persen, pada tahun 2012 persentase penerimaan retribusi pasar Youtefa kembali mengalami peningkatan yaitu sebesar 56,90 persen dan pada tahun 2013 persentase penerimaan retribusi pasar Youtefa ini kembali menurun yaitu sebesar 38,23 persen.

Pasar Youtefa mempunyai tempat yang strategis berada diantara Kota Jayapura dan Kabupaten Keerom, kedua masyarakat tersebut merupakan penghasil hasil bumi. Pasar Youtefa merupakan pusat grosir hasil bumi, maka memungkinkan Pasar Youtefa terus dapat meningkatkan penerimaan retribusi pasar, dengan fenomena tersebut seharusnya Pasar Youtefa menghasilkan pendapatan retribusi yang maksimal. Namun penerimaan retribusi pasar hingga tahun 2013 masih belum optimal.

Untuk itu penulis tertarik untuk menulis tesis dengan judul "Strategi Peningkatan Penerimaan Retribusi Pasar Youtefa, Sebagai Salah Satu Sumber Pendapatan Asli daerah Kota Jayapura", yang berlokasi penelitian di Pasar Youtefa dan Dinas Pendapatan Daerah Kota Jayapura sebagai organisasi publik yang diberi otoritas untuk mengelola retribusi pasar di wilayah Kota Jayapura.

Perbandingan realisasi penerimaan retribusi pasar dengan potensi yang ada di Pasar Youtefa masih rendah Rangkuti (2013). Hal ini dapat dilihat dari realisasi penerimaan masih banyak mengalami penurunan dan masih jauh dari target yang ditentukan di setiap tahunnya. Dengan demikian masih terdapat 40,5\% potensi retribusi pasar di Pasar Youtefa yang belum dapat dipungut dan dikelola dengan baik dilihat pada Tabel 3 berikut :

\section{Tabel 3}

Perhitungan Potensi Pasar Youtefa tahun 2013 berdasar pada Perda No 10 tahun 1999 tentang Retribusi Pasar (Rupiah)

\begin{tabular}{|l|l|c|c|c|c|c|}
\hline No & Nama & Banyaknya & Ukuran & Besar Tarif & Jumlah 1 Bulan & Jumlah 1 Tahun \\
\hline 1. & Kios (202) & 39 & $3 \times 3$ & 94.500 & 3.685 .500 & 44.226 .000 \\
& & 48 & $3 \times 4$ & 126.000 & 6.048 .000 & 72.576 .000 \\
& & 53 & $4 \times 4$ & 168.000 & 8.904 .000 & 106.848 .000 \\
& & 62 & $4 \times 6$ & 252.000 & 15.624 .000 & 187.488 .000 \\
\hline 2. & Los & 646 & - & $500 \times 30$ hari & 9.690 .000 & 116.280 .000 \\
\hline 3. & Pelataran & 289 & - & $50 \times 30$ hari & 433.500 & 5.202 .000 \\
\hline \multicolumn{7}{|c|}{ Jumlah } \\
\hline
\end{tabular}

Sumber, Data Pasar Youtefa (Data Diolah)

Tabel 3 diatas terlihat total potensi tahun 2013, selama 1 bulan sebesar Rp44.385.000 sehingga dalam jangka waktu 1 tahun total potensi sebesar Rp532.620.000. 
Berdasarkan sumber dari Pasar Youtefa realisasi penerimaan tahun 2013 Rp301.576.750 berarti penerimaan retribusi Pasar Youtefa belum optimal. Hal ini dapat dilihat dari rendahnya angka penerimaan retribusi dibanding potensi yang ada.

Berdasarkan uraian di atas dapat ditetapkan tujuan penelitian sebagai berikut : (a) Mengetahui perubahan lingkungan organisasi, baik lingkungan eksternal maupun lingkungan internal, dalam upaya meningkatkan penerimaan retribusi pasar; (b) Selanjutnya dengan berpedoman pada faktor kekuatan dan kelemahan, baik lingkungan eksternal maupun internal, diidentifikasikan isu-isu strategis yang dihadapi organisasi, sehingga dapat menyusun suatu strategi yang baik bagi upaya peningkatan kineija pegawai, dan guna meningkatkan penerimaan retribusi pasar.

Konsep manajemen keuangan Daerah menurut Halim (2013), manajemen keuangan daerah adalah "Pengorganisasian dan pengelolaan sumber-sumber daya atau kekayaan yang ada pada suatu daerah untuk mencapai tujuan yang dikehendaki daerah tersebut". Selanjutnya Ibnu Syamsi dalam Kaho (2013) menempatkan keuangan daerah sebagai salah satu indikator untuk mengetahui kemampuan daerah dalam mengatur dan mengurus rumah tangganya sendiri.

Masih dalam menurut Kaho (2013) menjelaskan pengertian retribusi daerah adalah pungutan daerah sebagai pembayaran atas pemakaian jasa atau karena mendapatkan jasa pelayanan pekerjaan, usaha atau milik daerah berkepentingan atau karena jasa yang diberikan oleh daerah.

Sementara itu Siagian (2005) menjelaskan Manajemen Strategis adalah serangkaian keputusan dan tindakan mendasar yang dibuat oleh manajemen puncak dan diimplementasikan oleh seluruh jajaran suatu organisasi dalam rangka pencapaian tujuan organisasi.

Sedangkan Salusu (2015). Menjelaskan Manajemen Strategik membicarakan hubungan antar organisasi dengan lingkungan, baik lingkungan internal maupun eksternal. Balikan manajemen strategik dapat membuat petunjuk bagi para eksekutif dalam mencoba mempengaruhi dan mengendalikan lingkungan untuk tidak sekedar bersikap memberikan reaksi terhadapnya, sehingga organisasi tetap mampu mengendalikan arah peijalanannya menuju tujuan sasaran yang dikehendaki

\section{METODE PENELITIAN}

\section{Lokasi, Pupulasi dan sampel penelitian}

Penelitian ini dilakukan pada Dinas Pendapatan Daerah Kota Jayapura yang diberi otoritas untuk mengelola Retribusi Pasar Youtefa sebagai salah satu pasar potensial yang saat ini penerimaan retribusi masih belum optimal. 


\section{Tehnik Analisis Data}

Untuk mempermudah analisis penulis akan menggunakan model sebagai berikut :

\section{Analisis Deskriptif}

Proses analisis atau teknik yang digunakan adalah sesuai tahapan yang dikemukakan oleh Miles (1984) dengan model interaktif yang merupakan siklus antara pengumpulan data, reduksi data dan sajian data serta penarikan kesimpulan seperti tergambar dalam gambar di bawah ini:

\section{Gambar 1}

\section{Model Analisis Interaktif}

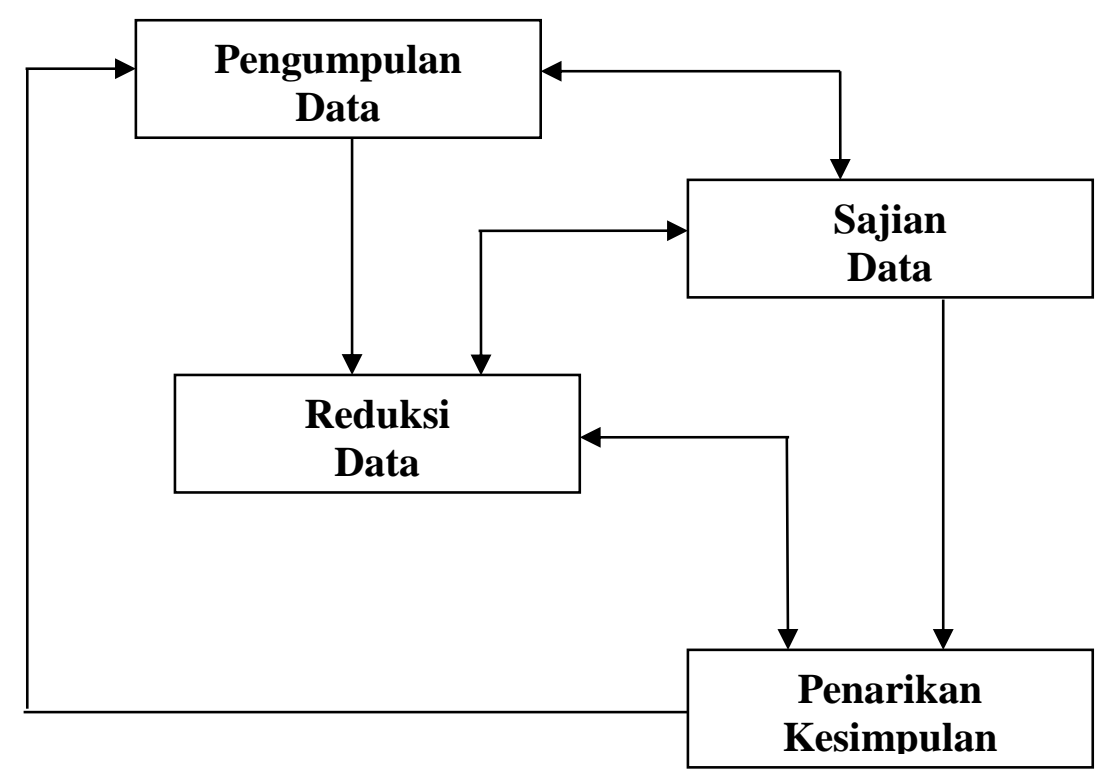

Sumber: Miles dan Huberman terjemahan (Tjejep Rohendi R, 1992)

\section{Analisis SWOT}

Langkah ini disusun berdasarkan pilihan-pilihan prioritas, logika dan waktu. Setelah diuraikan maka akan diuraikan analisis SWOT yang berisi pokok-pokok persoalan yang dihadapi Dinas Pendapatan Daerah sebagai organisasi publik yang diberi otoritas untuk mengelola retribusi pasar. Menurut Rangkuti (2013) analisis SWOT adalah identifikasi berbagai faktor secara sistematis untuk merumuskan strategi organisasi. Analisis ini didasarkan pada logika yang dapat memaksimalkan kekuatan dan peluang, namun secara bersamaan dapat meminimalkan kelemahan dan ancaman. Dengan kata lain analisis SWOT membandingkan antara faktor internal (kekuatan dan kelemahan) dengan faktor eksternal (peluang dan ancaman).

Faktor-faktor yang dianalisis adalah faktor yang ada di lingkungan Dinas Pendapatan Daerah antara lain mandat dan misi, lingkungan internal yang meliputi sumber daya, strategi, dan kinerja. Lingkungan eksternal meliputi faktor politik, ekonomi, sosial, teknologi, geografis wilayah, pelanggan, dan kolaborator. Setelah diidentifikasi baik lingkungan internal 
maupun eksternal lalu difomulasikan ke dalam tabel Interval Strategic Factor Analisis Summary (IFAS) dan Eksternal Strategic Factor Analisis Summary (EFAS) kemudian di analisis berdasarkan analisis SWOT untuk menentukan isu-isu strategis Dinas Pendapatan Daerah Kota Jayapura.

\section{PEMBAHASAN}

Keberhasilan suatu strategi dibutuhkan adanya konsistensi antara misi, mandat, isu strategis, sasaran, kebijakan program dan alokasi sumber daya. Setelah isu-isu strategis, tujuan atau visi keberhasilan bisa diidentifikasi maka langkah berikutnya adalah mengembangkan strategi untuk merespon isu-isu. strategis atau mewujudkan tujuan dan visi organisasi. Strategi yang akan dikembangkan pada organisasi Pasar Youtefa nantinya harus benar-benar mampu menciptakan jembatan antara organisasi dengan lingkungannya. Karena strategi adalah respon organisasi terhadap isu-isu strategis, maka strategi harus juga memberi outline dari tindakan organisasi dalam menghadapi isu-isu strategis.

Untuk kepentingan penulisan ini maka harus dilihat kembali hasil analisis lingkungan SWOT, karena dari analisis ini dapat dilihat dan diidentifikasi berbagai macam peluang dan tantangan serta kekuatan dan kelemahan yang dimiliki oleh Pasar Youtefa. Dari identifikasi peluang dan tantangan serta kekuatan dan kelemahan, kemudian diformulasikan menjadi strategi dengan menyusun pola hubungan antar aspek lingkungan dengan sebuah matrik SWOT, yaitu menggunakan kekuatan untuk menangkap peluang mengatasi kelemahan untuk mengambil peluang, menggunakan kekuatan untuk menghindarkan ancaman dan meminimalkan kelemahan dan menghindarkan ancaman. Untuk memperoleh gambaran yang jelas berikut akan digambarkan matrik SWOT untuk menyusun strategi yang harus dilaksanakan oleh Pasar Youtefa.

Tabel 4

Matriks SWOT dan Variasi Strategi Pasar Youtefa

\begin{tabular}{|c|c|c|}
\hline & Strength (S) & Weaknesses (W) \\
\hline Analisa & $\begin{array}{l}\text { - Otoritas/kewenangan yang } \\
\text { diberikan pemerintah Kota. } \\
\text { - Kejelasan mandat } \\
\text { organisasi Pasar Youtefa } \\
\text { - Prosedur pemungutan } \\
\text { retribusi pasar }\end{array}$ & $\begin{array}{l}\text { - Rendahnya pendidikan } \\
\text { formal dan minimnya } \\
\text { pendidikan fungsional } \\
\text { - Rendahnya kemampuan } \\
\text { keuangan untuk memenuhi } \\
\text { anggaran } \\
\text { - Kompetensi yang masih } \\
\text { rendah } \\
\text { - Lemahnya fungsi } \\
\text { pengawasan dan } \\
\text { penegakan hukum }\end{array}$ \\
\hline
\end{tabular}

Opportunities (O)

- Landasan hukum
- Dengan kewenangan dan
Strategi W-O

- Meningkatkan kemampuan 
pengelolaan retribusi pasar

- Pertumbuhan ekonomi yang cukup baik

- Peningkatan pendapatan masyarakat

- Pertumbuhan jumlah penduduk

- Pendidikan masyarakat

Threats ( $T$ )

- Ketertiban banyak pihak dalam menentukan tarif retribusi pasar

- Lemahnya penegakan hukum

- Belum adanya perangkat teknologi komputer

- Masih adanya infrastruktur \& fasilitas yang kurang memadai

- Bencana banjir yang sering melanda pasar Youtefa

- Rendahnya ketaatan mwmbayar pajak/retribusi

Sumber: data diolah mandat serta prosedur yang baik ciptakan pasar yang nyaman, aman, bersih dan tertib

- Penentuan target agar mendekati potensi yang ada dan ketrampilan pegawai

- Menciptakan budaya transparansi dan sosialisasi

\section{Strategi S-T}

- Memaksimalkan hasil retribusi pasar sesuai peraturan yang berlaku.

- Renovasi dan pembangunan fasilitas dan infrastruktur lainnya

- Kesadaran untuk membuang sampah pada tempatnya.

- Pemahaman yang sama dari semua pihak.

\section{Strategi W-T}

- Meningkatkan kualitas dan kuantitas personil

- Memperbaiki prosedur dan meningkatkan intensitas pengawasan serta penegakan hukum

- Penggunaan anggaran yang tepat sasaran

- Memberikan pemahaman tentang hak dan kewajiban

- Memperjelas tugas pokok dan fungsi

Setelah mengetahui kekuatan, kelemahan, peluang dan tantangan yang dihadapi Pasar Youtefa Jayapura dalam upaya mewujudkan tujuan organisasinya. Serta, berbagai variasi strategis, maka pada tahap selanjutnya melakukan penyusunan strategis yang mendasarkan kepada isu-isu strategis yaitu:

\section{Bagaimana meningkatkan kemampuan dan keterampilan pegawai Pasar Youtefa} dalam pengelolaan penerimaan retribusi pasar. sehingga tidak terjadi kesenjangan antara sumber daya personel Pasar Youtefa dengan perkembangan disiplin ilmu pengetahuan teknis dan manajemen pengelolaan penerimaan retribusi pasar dan pelayanan terhadap wajib retribusi dan masyarakat.

Pembahasan di atas telah memperlihatkan berbagai akibat yang ditimbulkan dari rendahnya kemampuan dan integritas pegawai yang ada pada Pasar Youtefa Jayapura, rendahnya kinerja baik dalam pelayanan maupun dalam upaya meningkatkan penerimaan retribusi pasar dan perencanaan yang hanya mendasarkan pada institusi, merupakan konsekuensi dari aspek ini. Oleh karena itu tuntutan bagi tersedianya tenaga yang terampil dalam pengelolaan keuangan daerah menjadi kebutuhan yang harus segera dipenuhi oleh Pasar Youtefa, jika memang menginginkan peningkatan kinerja pada Pasar Youtefa.

Sumber daya manusia pada Pasar Youtefa secara langsung berhubungan dan 
mempengaruhi perolehan dan peningkatan penerimaan retribusi pasar, oleh karena itu kualitas sumber daya manusia akan berpengaruh terhadap sistem pengelolaan retribusi pasar. Karena betapapun baiknya struktur organisasi dan lingkungan yang mendukung, namun apabila manusia atau aparatnya tidak mampu, maka pekerjaan akan mustahil dapat dilaksanakan dengan baik.

Oleh karena itu perlu upaya untuk mengoptimalkan para pegawai di lingkungan Pasar Youtefa dengan jalan antara lain: (1) penjelasan mengenai misi dan mandat yang diberikan kepada mereka, (2) peningkatan kemampuan dan keterampilan melalui pendidikan fonnal lanjutan maupun kursus-kursus, (3) penjelasan terhadap kekuatan, hambatan, tantangan, dan peluang dari instansinya. Upaya ini diharapkan dapat meningkatkan kualitas sumber daya manusia para pegawai di lingkungan Pasar Youtefa Jayapura.

Upaya akan mendorong para pelaksana untuk terus meningkatkan kinerjanya dan komitmennya terhadap tujuan organisasi. Arah dan tujuan yang jelas, pengetahuan aparat tentang permsalahan organisasi yang dihadapi akan melahirkan kesatuan gerak dan persepsi yang sama para pegawai di lingkungan Pasar Youtefa sehingga upaya mewujudkan missi organisasi akan mudah dilakukan.

Rendahnya pendidikan formal dan minimnya pendidikan fungsional pegawai dalam pengelolaan keuangan daerah khususnya pengelolaan retribusi pasar harus segera diatasi melalui pendidikan yang sifatnya crash program praktis dan berkesinambungan. Berbagai kursus dan 'pelatihan bagi petugas pemungut dan pengiriman pegawai untuk mengikuti kursus-kursus pengelolaan keuangan daerah dan pengelolaan Pasar merupakan solusi yang tepat bagi pegawai Pasar Youtefa sehingga perkembangan disiplin ilmu manajemen pengelolaan keuangan daerah khususnya pengelolaan Pasar serta penerapan teknologi komputer dapat terus diimbangi oleh kualitas personil yang ada. (Wawancara Kepala pasar Youtefa, 8 Agustus 2014)

Menyadari rata-rata tingkat pendidikan petugas pemungut retribusi pasar SLTA ke bawah dan mereka merupakan petugas terdepan untuk melaksanakan penarikan, menghimpun dan menyetorkan retribusi pasar maka agar petugas- petugas tersebut dapat melaksanakan tugas dengan baik dan sukses perlu ditingkatkan kemampuan dan keterampilannya melalui pelatihan petugas operasional yang meliputi:

1) Pengamalan dan penanaman metode pelaksanaan tugas yang efektif dan efisien.

2) Pembekalan, pemahaman dan penerapan disiplin.

3) Secara rutin dilakukan pembinaan mental spiritual.

4) Penanaman kejujuran bagi tiap petugas opersional.

Langkah dan kegiatan tersebut diharapkan dapat membentuk sikap mental yang mengarah pada disiplin kerja serta dapat meningkatkan kinerja petugas sehingga optimalisasi penerimaan retribusi pasar dan peningkatan pelayanan dapat terwujud. 
Peningkatkan kualitas pelayanan perlu selalu merespon apa yang diharapkan oleh masyarakat dan pembeli dilingkungan Pasar khususnya dalam rangka mewujudkan lingkungan Pasar yang aman, nyaman, dan bersih, sehingga dengan kepedulian ini akan berdampak positif melancarkan permasalahan retribusi pasar. Adapaun langkah-langkah nyata yang perlu dilakukan oleh Pasar Youtefa untuk meningkatkan kepuasan bagi pengguna jasa pasar antara lain:

1) Melakukan penataan yang tepat dan benar menurut komoditi yang ada, sehingga memudahkan bagi pembeli atau pelanggan untuk mendapatkan barang yang dicari.

2) Menyediakan lokasi tempat berdagang yang aman, nyaman, bersih dan layak bagi pedagang maupun pembeli, sehingga bagi pengguna jasa Pasar akan merasa nyaman selama melakukan aktifitasnya.

3) Mengoptimalkan keberadaan kawasan Pasar untuk peningkatan kepuasan bagi pengguna jasa Pasar.

4) Optimalisasi pelaksanaan keamanan dan ketertiban Pasar serta kebersihan lingkungan Pasar.

Uraian di atas menjadi jelas bahwa dalam upaya mewujudkan misi organisasi Pasar Youtefa baik dalam peningkatan pelayanan maupun peningkatan penerimaan retribusi pasar diperlukan strategi yang tepat dalam merencanakan kebutuhan sumber daya pegawai dilingkungan Pasar Youtefa baik dalam melakukan rekuitmen, penempatan maupun promosi pegawai.

Peningkatan kualitas dan keterampilan pegawai melalui jalur pendidikan dan keterampilan serta pengiriman pegawai pada berbagai pendidikan, diklat, dan kursus kursus merupakan upaya untuk menjamin tersedianya personil yang sesuai dengan kebutuhan organisasi.

Bagaimana meningkatkan dan memperbaiki prosedur pengawasan dan penegakan hukum di lingkungan Pasar Youtefa. sehingga kinerja organisasi meningkat dan optimalisasi penerimaan retribusi pasar dapat dilakukan.

Pengawasan dimaksudkan untuk mencegah dan mengurangi adanya penyimpangan atau penyalahgunaan terhadap retribusi pasar dengan maksud bukan untuk mencari kesalahan dan kemudian menghukumnya akan tetapi untuk mendidik dan membimbingnya.

Dengan demikian tujuan dari pengawasan yang dilakukan pada Pasar Youtefa adalah untuk mengetahui apakah pelaksanaan retribusi pasar sesuai dengan rencana yang telah digariskan atau tidak. Bila belum sesuai maka peran pengawasan menjadi sangat penting, karena lemahnya pengawasan meningkatkan terjadinya kebocoran dalam pengelolaan penerimaan retribusi pasar. (Wawancara Kepala Dispenda, 10 Agustus 2014).

Pengawasan yang sifatnya prefentif seharusnya dilakukan oleh Kepala Pasar karena 
Kepala Pasar langsung berhubungan dengan petugas pemungut retribusi pasar namun kendalanya adalah bahwa kepala Pasar tidak punya kewenangan secara formal untuk menilai stafnya yang dituangkan dalam DP3. untuk melaksanakan pengawasan yang sifatnya prefentif dapat ditempuh dengan cara sebagai berikut.

1) Menjelaskan secara rinci akan tugas pada masing-masing staf sesuai dengan prosedur yang ada.

2) Melaksanakan pemungutan retribusi pasar dengan system rotasi yaitu masing-masing petugas akan bergantian untuk melakukan pemungutan pada pos-pos yang telah ditetapkan.

3) Pengecekan terhadap pembukuan dari hasil setoran pemungutan retribusi pasar.

4) Diberikannya kewenangan kepada kepala Pasar untuk menilai stafnya dan memberikan sanksi bila memang diperlukan.

Langkah tersebut di atas, diharapkan pencegahan secara dini terhadap kemungkinan terjadinya kebocoran dan penyimpangan dalam pengelolaan penerimaan retribusi pasar dapat dihindari.

Disamping pengawasan internal organisasi yaitu pengawasan melalui organisasi Pasar Youtefa Jayapura, juga perlu pengawasan eksternal organisasi yaitu pengawasan yang melibatkan Bawasda (Badan Pengawas Daerah) yang saat ini dilakukan pemeriksaan selama 3 bulan sekali.

Lemahnya penegakan hukum akan berdampak buruk terhadap upaya optimalisasi penerimaan retribusi pasar untuk itu harus segera diatasi agar tidak menjadi bumerang bagi Pasar Youtefa di dalam memenuhi target yang telah ditetapkan. Upaya untuk menegakkan hukum dapat ditempuh dengan cara:

1) Penyuluhan terhadap pedagang akan hak dan kewajibannya.

2) Secara berkala dijelaskan ulang tentang besarnya tarif yang harus dibayar oleh pedagang sesuai dengan perda yang ada.

3) Menjalin kerja sama dengan instansi terkait seperti Satpol PP, untuk menindak pedagang yang melakukan pelanggaran berat sebagai wujud dari shock therapy agar pedagang lainnya tidak melakukan pelanggaran yang sama.

4) Segera dibuatkan Perda baru atau keputusan Walikota yang mengatur sanksi dan denda bagi wajib retribusi yang nakal.

Bagaimana meningkatkan tingkat kesadaran dan kepekaan pedagang terhadap norma-norma/ aturan yang berlaku. Kekurangsadaran masyarakat wajib retribusi pasar dilingkungan Pasar Youtefa harus dihadapi dengan hati-hati dan perlu "kelihaian" petugas pemungut untuk mengantisipasi perilaku pedagang yang tidak mau membayar retribusi pasar atau mau membayar tetapi tidak sesuai dengan perda yang berlaku. Menyikapi 
perilaku masyarakat wajib retribusi yang demikian maka perlu pendekatan sebagai berikut.

a) Pendekatan persuasif;pedagang diberikan penyuluhan karena dengan penyuluhan akan dapat menumbuhkan kesadaran pedagang terhadap kewajiban membayar retribusi. Melalui penyuluhan dan sosialisasi secara intensif, karena dengan penyuluhan dapat memberikan informasi yang benar dan jelas kepada wajib retribusi yang pada gilirannya akan menumbuhkan kesadaran untuk membayar retribusi bagi pengguna jasa dan fasilitas di Pasar.

b) Pendekatan represif; pedagang yang nakal diberi sanksi yang tegas agar tidak menjadi contoh yang kurang baik bagi pedagang lainnya.

c) Sikap dan tindakan pemungut harus baik, berdisplin tinggi, ramali dan selalu memberikan pelayanan yang prima kepada pedagang atau wajib retribusi.

d) Setiap dilakukannya kebijakan pedagang dilibatkan dan hasilnya disosialisasikan serta bersikap transparan sehingga wajib retribusi tidak merasa dibohongi.

Kebijakan dan praktek penentuan rencana target penerimaan retribusi pasar yang tidak didasarkan pada potensi retribusi pasar. Kebijakan dan penentuan rencana target penerimaan retribusi pasar yang tidak didasarkan pada potensi retribusi pasar merupakan isu strategis berikutnya yang akan mempengruhi missi organisasi dalam upaya meningkatkan penerimaan retribusi Pasar Youtefa Jayapura. Bahwa penetapan target penerimaan retribusi idealnya adalah dilakukan dengan mempertimbangkan dan mendasarkan pada perkiraan potensi.

Sehingga apabila target penerimaan tersebut tercapai, maka benar-benar akan mencerminkan efektifitas dalam pemungutan retribusi pasar. Seperti yang tergambar dalam Tabel 1 maka bisa dihitung dari Rp532.620.000,- potensi penerimaan retribusi pasar Youtefa hanya Rp301.576.750,- yang bisa dihimpun. Atau dapat dikatakan optimasi pemungutan retribusi pasar Youtefa baru mencapai 56,62\%.

Keengganan Pasar Youtefa untuk menggunakan angka potensi retribusi dalam penentuan target penerimaan retribusi pasar juga berkaitan erat dengan sistem penilaian keberhasilan sebuah organisasi penghasil income, pemahaman dan penilaian prestasi organisasi selama ini yang berlaku adalah seberapa besar organisasi penghasil pendapatan daerah dapat memenuhi target penerimaan yang dibebankan kepadanya. Sehingga menurut kepala Pasar terlalu riskan jika menggunakan potensi retribusi untuk menentukan rencana target penerimaan retribusi pasar, utamanya berkaitan dengan prestai organisasi yang dipimpinnya.

Upaya-upaya untuk menggunakan data potensi yang sebenarnya dalam melakukan perencanaan penerimaan target retribusi pasar sama dengan potensi yang sesungguhnya atau paling tidak mendekati potensi yang sebenarnya perencanaan kegiatan Pasar Youtefa yang selama ini lebih bersifat reaktif perlu dikembangkan pada perencanaan yang bersifat 
proaktif, dengan lebih memanfaatkan informasi-informasi dari berbagai dinas instansi terkait dan stakeholder, dalam melakukan upaya peningkatan penerimaan retribusi pasar seperti terlihat pada Tabel 5 sebagai berikut:

\section{Tabel 5}

\section{Permasalahan, Isu Strategis dan Strategi Pasar Youtefa}

\begin{tabular}{|c|c|c|}
\hline Permasalahan & Isu Strategis & Strategi \\
\hline $\begin{array}{l}\text { 1. Kualitas SDM yang } \\
\text { rendah } \\
\text { 2. Kurangnya sarana } \\
\text { informasi dan tehnologi } \\
\text { 3. Rendahnya aspek } \\
\text { kemampuan keuangan } \\
\text { 4. Perencanaan program } \\
\text { yang cenderung } \\
\text { mengulang } \\
\text { 5. Kinerja yang masih } \\
\text { rendah } \\
\text { 6. Keterlibatan banyak } \\
\text { pihak dalam } \\
\text { menentukan tarif } \\
\text { retribusi pasar } \\
\text { 7. Rendahnya penegakan } \\
\text { hukum } \\
\text { 8. Belum adanya sarana } \\
\text { tehnologi } \\
\text { 9. Fasilitas dan } \\
\text { infrastruktur yang belum } \\
\text { memadai }\end{array}$ & $\begin{array}{ll}\text { 1. } & \text { Rendahnya } \\
\text { kemampuan dan } \\
\text { ketrampilan pegawai } \\
\text { 2. } \\
\text { Rendahnya } \\
\text { pengawasan dan } \\
\text { penegakan hukum } \\
\text { 3. Masih rendahnya } \\
\text { tingkat kesadaran } \\
\text { pedagang akan } \\
\text { norma/aturan. } \\
\text { 4. } \begin{array}{l}\text { Penentuan target } \\
\text { yang tidak didasarkan } \\
\text { pada potensi. }\end{array}\end{array}$ & $\begin{array}{l}\text { 1. Peningkatan kualitas melalui } \\
\text { jalur pendidikan dan kursus } \\
\text { 2. Pemahaman dan sosialisasi } \\
\text { tentang apa misi organisai } \\
\text { 3. Penyediaan anggaran yang } \\
\text { cukup } \\
\text { 4. Perbaikan terhadap prosedur } \\
\text { kerja } \\
\text { 5. Penyuluhan dan sosialisasi } \\
\text { tentang hak dan } \\
\text { kewajibannya } \\
\text { 6. Menjalin kerjasama dengan } \\
\text { instansi terkait } \\
\text { 7. Dilakukan pendekatan } \\
\text { persuasif, pendekatan represif } \\
\text { 8. Peningkatan kualitas } \\
\text { pelayanan } \\
\text { 9. Komitmen/pemahaman yang } \\
\text { sama dengan semua pihak } \\
\text { 10. Melakukan perencanaan yang } \\
\text { matang dalam menentukan } \\
\text { target sehingga mendekati } \\
\text { potensi yang ada. }\end{array}$ \\
\hline
\end{tabular}

Sumber: data diolah

\section{KESIMPULAN}

Setelah melakukan penelitian dengan melakukan kajian kembali terhadap misi dari mandat organisasi, lingkungan ektemal dan internal analisis SWOT terhadap Pasar Youtefa maka isu strategis yang muncul adalah: (1) Rendahnya kemampuan dan keterampilan pegawai Pasar Youtefa dalam pengelolaan keuangan daerah khususnya pengelolaan penerimaan retribusi pasar yang terefleksi dari rendahnya pendidikan formal dan fungsional pegawai. (2) Rendahnya pengawasan dan penegakan hukum sehingga mempengaruhi kinerja organisasi dan upaya optimalisasi penerimaan retribusi pasar. (3) Masih rendahnya tingkat kesadaran dan kepekaan pedagang dan masyarakat terhadap norma/aturan yang berlaku. (4) Kebijakan dan praktek penentuan rencana target penerimaan retribusi pasar 
yang tidak didasarkan pada potensi yang ada.

Berdasarkan isu-isu tersebut diatas maka strategi yang dapat dipakai dalam upaya peningkatan retribusi pasar Youtefa, sebagai salah satu sumber pendapatan asli daerah kota jayapura adalah dengan cara peningkatan kualitas pelayanan melalui (1) pendidikan dan kursus bagi para petugas pemungut retribusi pasar, (2) pembenahan organisasi yang meliputi pemahaman yang baik terhadap misi pasar Youtefa, penyediaan anggaran pendukung aktivitas petugas pemungutan retribusi pasar Youtefa, perbaikan prosedur kerja baik secara internal ke dalam pengelola pasar Youtefa maupun secara eksternal dengan instansi terkait, serta adanya mekanisme perencanaan yang lebih baik guna pencapaian target yang lebih optimal sesuai potensi yang ada, (3) Pendekatan yang komprehensif kepada pelanggan dalam hal ini para pedagang di Pasar Youtefa dengan memberikan informasi melalui sosialisasi terkait hak dan kewajiban, sanksi dan tindakan yang dapat diambil oleh petugas, dan juga dibukanya komunikasi yang baik antara pengelola pasar dan pelanggan guna menimbulkan suasana yang nyaman di pasar Youtefa, (4) Perbaikan infrastruktur dan fasilitas pendukung di pasar Youtefa, serta (5) Dibangunnya komitmen bersama dalam rangka mencapai tujuan pembangunan secara khusus dalam rangka peningkatan Pendapatan Asli Daerah Kota Jayapura.

\section{DAFTAR PUSTAKA}

Halim, A. (2013). Akuntansi dan Pengendalian Keuangan Daerah (Empat). Jakarta:

Salemba.

Kaho. (2013). Prospek Otonomi Daerah Di Negara Republik Indonesia. Jakarta: Rajawali Pers.

Miles B, A. M. H. (1984). Ouantitative data analysis: A Sourcebook o f' New Methods.

Rangkuti, F. (2013). Strategi promosi yang kreatif dan analisis kasus. Gramedia Pustaka Utama.

Salusu, J. (2015). Pengambilan Keputusan Stratejik. Gramedia Widiasarana.

Santoso, B. (1995). Retribusi Pasar Sebagai Pendapatan Asli Daerah: Studi Kasus Pasar Kabupaten di Sleman. Prisma, (4), 19-35.

Siagian, S. P. (2005). Manajemen stratejik. Bumi Aksara, Jakarta. 